Please cite the in-print version of this text at:

Sideeq Mohammed (2019) Understanding microfascism: reading Deleuze and Guattari alongside management guru texts, Culture and Organization, DOI: $\underline{10.1080 / 14759551.2018 .1563604}$ 


\title{
Understanding Microfascism: Reading Deleuze and Guattari alongside management guru texts
}

Sideeq Mohammed

Kent Business School. University of Kent, UK.

s.mohammed@kent.ac.uk

ORCiD: 0000-0003-2046-5465

\begin{abstract}
The 'management guru' text has long been a source of interest for academic audiences. In this tradition, this paper argues that the content and underpinning ideology of the guru guide hold important insights for organizational scholars interested in the works of Gilles Deleuze and Felix Guattari (and vice versa). Specifically, this paper will demonstrate that a close reading of entrepreneur and guru, Tim Ferriss's, Tools of Titans, can provide meaningful exegesis and development of the concept of 'microfascism' presented by Deleuze and Guattari across their shared and independent corpuses. Building upon extant organization studies literature, this paper will endeavour to contribute to the commentary on the management guru by suggesting that the desire for fascism, power, conformity, and rule-following of which Deleuze and Guattari speak offers a productive way of understanding the success of the management guru and the broader allure of the management advice industry.
\end{abstract}

Keywords: Deleuze and Guattari, microfascism, management guru, desire, politics of organization 


\section{Understanding Microfascism: Reading Deleuze and Guattari alongside management guru texts}

\section{Introduction: Thinking with concepts}

How do we explain the popularity of the 'management guru' and the broader success of the lucrative management 'advice industry' of which they are a part? This paper aims to develop the concept of 'microfascism' as a way of understanding the management guru, and specifically the management guru text, by using the example of Tim Ferriss's (2016) Tools of Titans. Due to its pervasiveness and popularity among practitioners and the general public, the management guru text has become a key focal point for academic analysis (Huczynski 1992; Clark and Salaman 1996; Clark and Salaman 1998; Jackson 2001; Collins 2005; Collins 2008; ten Bos and Heusinkveld 2007). This paper finds that an analysis of the management guru text renders apparent the complex of psychosocial forces that underpin its popularity and also sheds light on the limits of 'microfascism' as a philosophical and political concept.

Microfascism, a yearning for fascistic repression and control that exists within all of the members of a society, is a concept that was originally developed in the works of French philosophers, Gilles Deleuze and Felix Guattari, whose writings have found much favour in management and organization studies in recent years (Chia 1999; Styhre 2002; Thanem 2004;

Clegg, Kornberger, and Rhodes 2005; Sørensen 2005; Linstead and Thanem 2007; Pedersen and Kristensen 2016). What Deleuze and Guattari allow us to develop within the field of enquiry focused on gurus and the guru text is a more robust understanding of the politics of contemporary organization. This is a understanding of politics that is more capable of apprehending the nuances of the interrelation of what might be termed 'structural' and 
'individual' political action, and also one that is ethically (see Parker 2003) capable of responding to broader political challenges, as well as those posed by the management guru.

What this paper shall suggest is that the question of microfascism is entangled with the issue of why managers, students of management and wider public audiences are so drawn to the persona and writings of the management guru. There is a particular draw of power, a lust to dominate and be dominated, to follow rules and see others conform to them, that operates throughout the social fabric in ways that shape how we participate in and understand social organization. As we shall unpack, Deleuze and Guattari see this microfascism, this draw of power in the everyday or at the micro-level, as inextricably linked to broader state or macro-level political phenomenon like state fascism. We argue for the need to be better attuned to this psychosocial complexity because it speaks to a complex of desire and anxiety which produces and is produced by a social milieu where the guru is not only popular but a 'critical' or alternative answer to the demands of contemporary social life. We shall unpack that the management guru's success comes because they trade in the sale of a particular image of freedom which serves as a form of mutual comfort in an organizational world of uncertainty and ambiguity. This 'freedom' accorded to the neoliberal subject is reflective of the development of the management advice 'industry' - which Collins (2016; Forthcoming) more accurately describes via Latour as an interrelated network of managers, business schools, academics, business press, publishers, editors, and the gurus themselves - as a mode of control (see Garsten and Grey 1997) .

This paper is structured as follows. In the first section, we shall reflect upon the extant organizational literature which speaks critically of the management guru and the various forms of advice and management ideas that they offer. Having thus explored the ways in which these 
debates can be reopened and extended in order to facilitate a more robust understanding of why we are so drawn to the guru, we shall, in the second section, address ourselves to the consideration of the concept of microfascism and develop out of it a new understanding of the complexity of the relationship between the guru and their audience or client. Finally, we shall consider in depth the ways in which Tim Ferriss's Tools of Titans, which we take as a text indicative of a resurgent genre of guru/self-help literature, can elucidate and expand upon this concept, thereby enabling us to conclude with a provocation of some of the potential strategies available for a politics of organization considered in this way.

\section{Understanding the guru guide}

The 'management guru' is defined by the excellent work of Clark and Salaman (1998, 138) as a figure whose work involves:

the presentation of ambitious claims to transform managerial practice, organizational structures and cultures and, crucially, organizational performance, through the recommendation of a fundamental almost magical cure or transformation that rejects the past, and reinvents the organization, its employees, their relationships, attitudes and behaviour.

Draped in demagoguery, the guru is often one who is construed as a visionary and messianic figure, able to provide guidance to the organization and its management in confusing times. To use the categories of Huczynski (1993a), one can see examples of the management guru's work in hugely popular texts like those of 'hero-managers' such as Iacocca's An Autobiography (Iacocca and Novak 1987), consultancy informed texts like Peters and Waterman's (1982) In Search of Excellence, or more academic texts like Henry Mintzberg's (1973) Nature of 
Managerial Work. To these we might add the newly popular texts of the quasi-self-help genre including Covey's The 7 Habits of Highly Effective People, Carnegie's (1936) How to Win Friends and Influence People, and more recent entries to this genre like Ferriss's Tools of Titans. These have escalated in popularity with growth of what Cederström and Spicer (2015) call the 'wellness syndrome' in the context of a broader vogue of ideas of how to continuously optimize and improve oneself.

Since the late 80 's and early 90 's many organizational scholars have offered detailed catalogues of the differing typologies of guru or consultant (Huczynski 1993a) as well as insightful and incisive commentary of the means by which the management guru might perform their role as an organizational 'witch-doctor' (Clark and Salaman 1996; Micklethwait and Wooldridge 1996), who peddles various 'flavours of the month' (Watson 1994) or other forms of mysticism to be considered by managers. Indeed, the pervasiveness of figures like the everpresent Peter Drucker or the popular Tom Peters (Collins 2008; Collins 2011) and others who, for Huczynski (1993a) gained their popularity in the 1980s and built small empires around book publishing and extremely lucrative public lectures, has meant that there is no shortage of academic commentary on them or their successes.

Historically, the management guru has also been implicated in popularity of various ‘fads' (Huczynski 1993b), 'fashions' (Abrahamson 1996; Abrahamson and Fairchild 1999; Benders and Van Veen 2001; Jackson 2001; Clark 2004), or 'fads and fashions' (Abrahamson 1991; Newell, Robertson, and Swan 2001). Extant research traditions have also done much to place the guru into the context of the rise of the many popular 'fashions' that exist within the world of business and management including lean management (McCann et al. 2015), Total Quality Management (Legge 2002), flexible working/work-life balance (Whittle 2008), and 
Business Process Reengineering (Willmott 1994; De Cock and Hipkin 1997). Others, however, remain critical of the dismissive tone of much of the literature on 'fads' (Collins 2001) and have significantly reflected upon the ways in which the analysis of gurus and guru theory can contribute to serious academic scholarship (Collins 2005) .

However, while other scholars have sought to categorize or demonstrate the flaws in the efficacy of guru ideas or reject guru theorization on the grounds that various fashionable ideas can have negative consequences for people at work, it is this paper's concern to participate in and further the discussion around the comparatively less researched area of the appeal of the guru in such a way that can fully address the truly pervasive nature of the socio-organizational phenomenon of their work (Greatbatch and Clark 2005).

In an excellent meta-analysis that builds particularly on the work of Grint (1997), Jackson (2001) posits four approaches to understanding why the guru finds success: rational, structural, charismatic and institutional/distancing. To summarize, gurus succeed because their ideas work and have practical utility for organization; because the situation faced by the business at a particular time seems to be addressed by the guru's ideas; because they have unparalled abilities to perform, self-promote and market their ideas; or because managers are pressured into 'bandwagoning' onto successful guru ideas out of fear that their adoption by competitors will create an unassailable competitive advantage. While each of these has its veracity and while each offers important insight into the guru's popularity, we suggest that there is still scope for the body of literature which assays the problem of the appeal of the guru to be expanded. As Salaman (2002) suggests, while many authors have considered why we seem so drawn to the ideas of the guru and why we seem so willing to adopt their new ideas and idolize them as leaders, comparatively few have developed robust theorization of why this is the case. 
To wit, much of the early work in this area focused on the gurus themselves, their charisma, the accessibility of their message, their performance, their oration in the course of a lecture and their ability to link their message to relatable experiences that resonate with their audience in ways which at once heighten and ameliorate anxiety (Carlone 2006). For example, Huczynski (1993a), pragmatically suggests that the guru succeeds because their ideas emerge in a timely, well-marketed, easily intelligible and relatable manner. This kind of account is underdeveloped insofar as it explains away the enthusiastic adoption of guru ideas with bandwagoning or simply fashionability, neglecting thereby the collusion of the manager/client who adopts the guru's ideas. Indeed, for Collins (2005), much of this work problematically paints the manager who seeks out the guru's insights as passive or preyed upon and thus ignores their involvement and complicity in the guru's success. Congruently, Sturdy's (1997) study of IT consultants highlights the role of anxiety and systematic insecurity among managers in this process, suggesting that there is a much more complex relationship than simply predator and victim, seducer and seduced. Rather, Sturdy $(1997,408)$ suggests that there is reciprocal anxiety on both sides, concluding that 'greater attention should be given to the interactive nature of the process and, in particular, to the active role and resistance of client managers and to consultants' own insecurities.' Similar insights might be applied to theorizing the relationship between gurus and their readers/audiences. Relatedly, other authors also note the tendency of analysis to neglect the client's tendency to mix and match advice from different sources, thus creating their own pastiche of 'insight' into the world of organizations. As Gabriel (2002, 140-141) posits 'consumers adapt objects to highly specific, often ad hoc uses, devising unique combinations and variations.' That is to say, far from being innocent dupes, readers actively seek out the advice of 
gurus and choose from the many available sources the inspiration, insight and quips that best suit their situation.

Extending the debate in a similar manner, Clark and Salaman (1998) suggest that what makes these texts appealing is less the uncertainty and anxiety of managerial work and less the charismatic nature of the gurus themselves and more the fact that these works construct the manager as a heroic, visionary and transformational figure; distracting from the mundane nature of managerial work (filling out the right forms, attending meetings, planning etc.) with a fantasy of becoming a quixotic and charismatic leader. The relationship between the reader or manager and the guru is thus one of mutual identity construction, where the guru's work constructs a narrative which legitimates and charts the manager's role within the organization, thereby facilitating the construction of a more aspirational identity politic while the guru is construed as the apex of these aspirations. ${ }^{1}$ However, few papers consider these anxieties within the broader social context of their reflection of and production by a given social fabric (see Garsten and Grey 1997 as an exception).

That is to say, many of the aforementioned scholars hold that accounts of the rise of the guru and the business of consulting neglect the complicity of managers/clients in the demand for the guru's services by painting them as passive actors or victims and focusing instead on the charm, sophistication and salesmanship of the guru, and have found reasons for the guru's success in a variety of factors - particularly anxiety and insecurity. However, the continued pervasiveness of guru texts needs to be placed in the context of a broader psychosocial analysis of the reasons for our collective solicitation and co-development of their body of work. We

\footnotetext{
${ }^{1}$ There are strong resonances here with the work done within Critical Leadership Studies (Collinson 2003; Collinson 2011; Alvesson and Spicer 2012) which seeks to deconstruct some of the fundamental assumptions of leadership or otherwise call into question the draw of the leader and by their celebration by followers. Indeed, it is our contention that the same forces that lead us to seek out the judgement and guidance of a leader within the organization are the ones that serve to legitimate and inform the desire for the management guru's advice.
} 
reiterate that the full psychosocial complexity of the draw of the guru is yet to be fully developed, taking into account the rich politics of their engagement with general audiences or managers. Here we suggest that Deleuze and Guattari's understanding of politics, encapsulated in the idea that "everything is political, but every politics is simultaneously a macropolitics and a micropolitics' (Deleuze and Guattari 2005, 213), stands to offer us an insightful way of reconceptualising this problem by allowing us to understand the interplay of large, macro, institutional phenomenon and the everyday or micro occurrences of anxiety or identity construction that produce the appeal of the guru. As such, in the subsequent section, we shall develop the concept of 'microfascism' in the work of Deleuze and Guattari and thereby propose that it can offer insight into why we so actively seek out the wisdom of the guru.

\section{Discussing fascism in Deleuze and Guattari}

Though rarely considered as one of their core or most important concepts, 'microfascism', and the preoccupation with a micropolitics that Deleuze and Guattari develop in their work, stands to be one of the most productive ways of thinking about politics in the contemporary milieu. Despite this, while Deleuze and Guattari's works have been increasingly a preoccupation for many in management and organization studies interested in the question of organizational politics (see Fuglsang and Sørensen 2006) the question of microfascism has yet to be fully explored. Even where it is considered (see Fuglsang and Böhm 2003), the concept is not developed in significant depth as a resource for understanding the way in which organization takes place or parsing the complex of decisions and drives that inform our politics.

Correlatively, organizational scholars have yet to fully explore the implications of what this paper contends to be one of the most poignant and relevant questions in Deleuze and 
Guattari's shared corpus: 'Why did the masses desire fascism?' This question, posed by Deleuze and Guattari $(2000,345)$ out of their reading of the psychoanalyst, Wilhelm Reich, is perhaps the single sentence in their work that has the most capacity to speak meaningfully to the state of the politics of organization at the present social moment. Posed in the context of their attempts to develop a more robust conceptualization of 'desire' as a psychosocial force, they suggest that 'only microfascism provides an answer to the global question: why does desire desire its own repression, how can it desire its own repression?' (Deleuze and Guattari 2005, 215).

Building off of Thanem (2004), it is worth noting two things about this conception of 'desire' in brief. Firstly, when Deleuze and Guattari speak of 'desire' they are not speaking of merely a want of something, nor are they referring to a Lacanian 'lack'. Rather, they are speaking of a productive, disindividuated and polymorphous force which serves as an impetus and a drive to life. Secondly, it is also worth noting that 'the social' codifies and controls desire by its very operations. As they say in Anti-Oedipus, 'no society can tolerate a position of real desire without its structures of exploitation, servitude, and hierarchy being compromised' (Deleuze and Guattari 2000,116). Desire is free, open and creative until it encounters the engagements that characterize everyday social life which shape and determine it.

Returning to Deleuze and Guattari's question about desire and repression, what we must unpack is the rather uncomfortable proposition that the mass macropolitical fascism which swept across Europe in the mid-twentieth century (particularly in Germany and Italy) was not an accident, or the product of a malevolent and destructive few, but rather was the result of a deeply held desire for power, and consequently repression and unfreedom, common to all. That is to say, that the proliferation of fascisms on a micropolitical level occurs concomitantly with and inextricably connected to the development of a fascistic state apparatus. As Holland $(2008,76)$ 
succinctly puts it: 'mid-century European masses weren't ideologically tricked into fascism: they actively desired it because it augmented their feelings of power.' In what follows, we try to unpack the significance of the question of the desire for fascism as it appears in various forms throughout Deleuze and Guattari's co-authored and individual works because it is this paper's contention that the microfascistic desire for repression offers an interesting alternative to understanding the appeal of the management guru than the models which we currently employ.

It is difficult to trace the 'origins' of microfascism as a concept. ${ }^{2}$ Some early intellectual threads of its formation appear perhaps in Intellectuals and Power, a 1972 interview between Deleuze and Foucault, where Deleuze $(2004,212)$ comments: 'we must be willing to hear Reich's cry: No, the masses were not fooled, they wanted fascism at a particular moment!'. Here Deleuze perhaps speaks in direct reference to some of the comments that he would make with Guattari in Anti-Oedipus which was published in the same year:

after centuries of exploitation, why do people still tolerate being humiliated and enslaved, to such a point, indeed, that they actually want humiliation and slavery not only for others but for themselves? [...] the masses were not innocent dupes; at a certain point, under a certain set of conditions, they wanted fascism, and it is this perversion of the desire of the masses that needs to be accounted for. (Deleuze and Guattari 2000, 29)

In examining some of Guattari's work, his preoccupation with fascism becomes apparent in a concern for the evolving 'microscopic fascisms' (Guattari 1984, 62) that characterize the social through their codification of desire. This can be seen particularly in the 1973 lecture, transcribed

\footnotetext{
${ }^{2}$ While one can only speculate as much, it is worth noting that the term only appears in Deleuze's work with Guattari or interviews given in the 1970's and 80's, lending credence to the reading that the events of May ' 68 proved to be a watershed moment for Deleuze's intellectual project. This is one that would shape his subsequent work towards being able to explain its failure, and by consequence, the rise of fascism across Europe in the 1930's and 40's as congruent with the rise of the French far-right and the Front National in the early 70's and the Parti populaire français more generally.
} 
into the essay Everybody wants to be a Fascist, which speaks overtly to this concern of why and how we might come to actively desire overt fascistic repression, as well as the ways in which the components of a state level fascism are present in contemporary social institutions like the school or the family, simply waiting to be drawn out. As he says: 'I repeat: what fascism set in motion yesterday continues to proliferate in other forms, within the complex of contemporary social space' (Guattari 2009, 163). For Guattari, the consideration of microfascism is a part of a broader project which involves the understanding of desire and the disruption of the micro/macro or psychoanalytic/political distinction, thus enabling the consideration of a politics on the level of the individual and a treatment of desire on the societal scale.

As such, a distinction needs to be clarified here, between the large scale state-level fascism that is being discussed by Reich and, by consequence, Deleuze and Guattari, and the codification and control of desire which tends to express itself in fascistic tendencies that they go on to describe as microfascism. Perhaps the most significant hurdle to achieving such an understanding of the use of the term 'microfascism' as it appears in Deleuze and Guattari's work, is that there is no academic consensus on what 'fascism' means in a general sense or as a State phenomenon. For example, Massumi $(1992,116)$ speaks of fascism as 'a manic attack by the body politic against itself, in the interests of its own salvation [...] it is desire turned against itself.' That is to say, in a desire to pursue our own self-interest we can be made to act against our own interests by constructing and participating in a repressive politics. However insightful, this kind of explanation, common to scholarship on Deleuze and Guattari, offers little in terms of an operational definition of fascism. As historian David Renton (1999) notes, there is little agreement as to what 'fascism' might be defined as or indeed, how one should define it (whether one should consider historical movements and distil their common elements or seek some 
underpinning ideological tenets etc.). Attempts by authors like Umberto Eco (1995) to do the latter by identifying 14 characteristics of an "Ur-fascism" have not been widely taken up definitionally. Even if we accept a working definition like that offered by Passmore (2002) in the following, and necessarily contextualize this fascism as a socially conservative, far-right movement that rejects socialist and feminist ideals, it does not wholly address what Deleuze and Guattari are alluding to in their discussion of microfascism:

fascism is a set of ideologies and practices that seeks to place the nation, defined in exclusive biological, cultural, and/or historical terms, above all other sources of loyalty, and to create a mobilized national community. (Passmore 2002, 31)

Rather, this kind of definition speaks to the macropolitical or state level aggregation of micropolitical fascistic phenomenon. As Deleuze and Guattari say explicitly, their concern for the latter is with:

rural fascism and city or neighbourhood fascism, youth fascism and war veteran's fascism, fascism of the Left and fascism of the Right, fascism of the couple, family, school and office. (Deleuze and Guattari 2005, 214)

For them, fascism is a phenomenon that is most pervasive and important to comprehend on the micro-level, dissipated throughout the social fabric, rather than concentrated in a government. In a short 1976 essay titled The Rich Jew on the subject of antisemitism in film Deleuze explains why it is crucial to develop this micropolitical understanding of fascism:

Oldstyle fascism, however real and powerful it may still be in many countries, is not the real problem facing us today. New fascisms are being born. The old-style fascism looks almost quaint $[\ldots]$ compared to the new fascism being prepared for us. All our petty fears will be organized in concert, all our petty anxieties will be harnessed to make micro- 
fascists of us; we will be called upon to stifle every little thing, every suspicious face, every dissonant voice, in our streets, in our neighbourhoods, in our local theatres.

(Deleuze 2006, 137)

Deleuze is here writing in critique of the banning of the film L'Ombre des anges by Daniel Schmidt, and is arguing that the fascism to be feared is not that of the Nazis or indeed any other far-right party, but that which leads us to suppress the images of their violence. This is as vivid a description as one can hope for of a world where fascism is not only an organized political philosophy but a stifling of thought, of otherness, of difference; an aggregate destructive yearning for power here understood as manifested in the profound desire for and proliferation of homogeneity, uniformity and control.

This is where and why a micropolitics becomes important to understand and engage in a practice thereof. Writing together in A Thousand Plateaus, Deleuze and Guattari $(2005,215)$ suggest that it is easy to oppose state or macrolevel fascism 'and not even see the fascist inside you, the fascist you yourself sustain and nourish and cherish with molecules both personal and collective.' It is the 'fascist inside', what Foucault, in his introduction to Anti-Oedipus, explicitly calls out as the fascism within us all which manifests in our everyday behaviours, in our anxieties, our love of power and our lust for the structures and relations which supress and control us. Deleuze and Guattari describe this effect of the social milieu as follows:

As we have seen, microfascisms have a specificity of their own that can crystallize into a macro fascism $[\ldots]$ Instead of the great paranoid fear, we are trapped in a thousand little monomanias, self-evident truths, and clarities that gush from every black hole and no longer form a system, but are only rumble and buzz, blinding lights giving any and 
everybody the mission of self-appointed judge, dispenser of justice, policeman, neighbourhood SS man. (Deleuze and Guattari 2005, 228)

To emphasize, it is its occurrence on the micropolitical level, that of everyday life and encounters, which Deleuze and Guattari believe makes fascism truly dangerous, transforming the free individual into a 'neighbourhood SS man'. This fascism on the level of the everyday finds expression in a number of simple examples which characterize organizational life (e.g.: the anger that we feel when someone cuts in front of us in traffic on the drive to work, when they don't wait for us to get off the elevator before trying to get on, when they don't replace the paper in the communal printer, or break an informal dress code etc.). What is crucial to note is not the anger or outrage that we feel but the way in which it reflects that we not only want to 'follow the rules' which come to be taken for granted as a part of the social order, but we want others to demonstrate the same discipline and conformity; we want them to want to follow the rules and feel a curious anger or misplaced anxiety when they are either ignorant of or indifferent towards them. That is to say, desire desires that nothing escapes the regimes of coding and control to which it has been subjected. This is the 'fascist inside' us, the microfascist impulse, the codified and socialized desire that comes, in Deleuze and Guattari's terms, to desire its own repression. Microfascism speaks to a profound desire for more organization, for more management, for more order and control, for (insofar as we define 'the social' following Deleuze and Guattari as that which codifies and restricts desire) social life.

In sum, the answer to the question of the desire for fascism is a nuanced complex of desire that goes beyond a simple existential 'fear of freedom' (Fromm 2001), beyond the class based analysis of a Marxist 'false consciousness' and to a more substantial desire for power and authority that is beyond even Nietzsche's 'will to power'. Historically fascistic leaders have been 
able to mobilize this desire for various forms of social conservatism which manifest as a desire not only for rules, order, control, safety etc. but for these rules to be followed, enforced and even loved. It is crucial in reflecting upon contemporary politics that we both observe these everyday micro-level fascisms and extrapolate from these microfascisms in order to see the emergence of the grand, state-level political movements which represents an extreme politics, an impulse towards rule-following, tradition and conformity which crucially begins with the desire of and for repression.

It is thus that we must return our attention to the 'management guru', for in their conduct we can see evidenced the microfascist impulse that Deleuze and Guattari describe, as well as scope for developing the concept beyond Deleuze and Guattari's writings. That is to say, the relationship between the guru and the client/manager, and by proxy the entire management advice 'industry', reveals itself to be located at the nexus of demagoguery, desire for unfreedom and control, existential angst, and the need for conformity, all of which can speak to and learn from Deleuze and Guattari's preoccupation with the codification and control of desire as a social force. Desire can be so perverted that it actively seeks out demagogues, courts disciplinary regimes, and champions causes that create repression and suppress freedoms. In the subsequent section, we will examine in detail the ways in which Tools of Titans can help us to understand this complex of desire.

\section{Tools of Titans: Microfascism as critique}

With the resurgence of authoritarian 'strong man leadership' and the cult of personality around leaders in Western politics and popular culture, it is perhaps no surprise that Tools of Titans: The tactics, routines and habits of billionaires, icons and world-class performers was near the top of 
many 'Bestselling Books about Leadership' at the close of 2016. The author, Tim Ferriss, is well known for his image as a successful investor and entrepreneur, with his previous titles like The 4-Hour Workweek or The 4-Hour Body centring on the notion of a '4-hour life' (workouts, cooking, work habits etc.) and trading upon this in order to sell a rhetoric of increasing efficiency and optimizing everyday life. This work has drawn the attention of organizational scholars who have regarded it within a prevailing discourse of self-management which Spicer (2018) contextualizes as being within the purview of what he eloquently terms 'business bullshit'. With Tools of Titans Ferriss broadens his scope, offering lessons from the nearly two hundred individuals who he terms 'world-class performers' that he interviewed over a number of years in the course of running a highly commercially successful podcast.

On the surface, Ferriss's work does not seem to conform to the standards and categories used classically to typify gurus (e.g. Huczynski 1993a); he is hardly an 'academic guru', does not have the experience to be a 'consultant guru', and because of his experience as an investor in business start-ups perhaps only barely qualifies as a 'hero manager'. However, his work fits into the broader trend in the advice industry towards self-help and life-coaching (Cederström and Spicer 2015). Garsten and Grey $(1997,212)$ refer to these as 'how to books' for managers, selfhelp books reflective of a post-bureaucratic world and the 'intellectual and cultural terrain of postmodernism which simultaneously suggests a collapse of certainty whilst promoting the role of expertise.' We follow this trend of work in suggesting Ferriss as a guru for the present sociocultural moment. Indeed, in 2017 The Observer heralded Ferriss as 'one of our age's most influential self-help gurus' (Lewis 2017). Further, as we shall develop, Ferriss's charisma and charm bears out many of the tropes classically associated with the management guru, making his 
text an important site of concern as both an instance of popular management literature and as an example of the new currents and trends in the world of guru writing.

In order to assay specifically how Tools of Titans can develop both our understanding of the appeal of the 'management guru' and our conceptualization of 'microfascism', we will separate our analysis into a consideration of firstly the content and, secondly, the tone or tenor of the text. In terms of content, Tools of Titans contains over a hundred 'profile chapters', each focusing on some leader, visionary, or person of note whose characteristics, qualities, and successes are extolled by Ferriss and distilled into concise and editorialized formats so that the reader can easily digest their advice. The star-studded list of these leaders and 'world-class performers' includes Olympic gymnastics coaches, Professors and PhD's in everything from Molecular Pharmacology to Neuroscience, medical doctors, CrossFit trainers, professional wrestlers, high-profile investors fresh off the cover of Forbes magazine, politicians, developers and founders of some of the mainstay websites of the contemporary internet, Oscar nominated film-makers, hedge fund managers, professional snowboarders, CEO’s, master chefs, Navy SEALs, Grammy nominated musicians and popular actors. These all have a small space in Tools of Titans to share their wisdom and insights on life and being 'successful' at living and working within the contemporary social milieu.

Readers may well be surprised at how conclusive the book is in its prescriptions and general life advice; containing unambiguous life-direction on topics as diverse as mattress buying (Ferriss 2016, 126), the secret to making good eggs (p.559), a section on 'tactics for dealing with haters' (p.534) and advice on avoiding MBAs which amount to a '2-year vacation that looks good on the resume' (p.250). Tools of Titans contains innumerable suggestions of what to eat, what kind of music one might listen to, what kinds of questions to ask, and what 
books one should read and so on. To a degree it presents an aspirational and selftransformational narrative which unambiguously gives direction and tells its readers how to manage (in the broadest, social sense of this term - self-management and beyond). Here Ferriss's work makes sense in light of discourses that suggest that 'we are all managers now' (Grey 1999) and other rhetoric that represents individual freedom as a means of control in the context of postbureaucratic organization (Garsten and Grey 1997; Maravelias 2003). Ferriss's work seems to offer a clear response to the perilous politics of identity, power, and anxiety that governs modern life in the general context of late-stage capitalism: follow these instructions and you will be fine. Here Ferriss is to be truly admired for the ways in which the text actively constructs its reader: an individual in organization struggling for a sense of purpose or direction, likely to be enchanted by stories of 'titans' who were successful through a series of habits or qualities that we too can cultivate.

Here we can see the veracity of the analysis by organizational scholars who have commented on the ways in which the guru trades in various forms of shamanism and heroworship with the constant emphasis on adopting the life habits of the 'titans'. Ferriss's description of various health and wellness routines evoke the image of the transformation of a man or woman into some manner of drug-enhanced, low-body-fat, investment-savvy management guru who speaks only in maxims about self-reinvention and 'pivoting' rather than regarding either the messy nuance of the modern corporation or the complexity of the existential problems of the human experience in the context of neoliberal capitalism. Indeed, Ferriss's starstudded list of 'Titans' itself lends credence to Abrahamson's $(1996,268)$ assertion that the management guru 'must not only create the belief that the techniques they champion are rational, but also that they are at the forefront of management progress.' We here also reflect that for 
Clark and Salaman (1998), guru theory does not try to solve managers' problems, nor does it supply answers to the pressures and struggles that they face in role but rather, it constitutes the role of the manager itself. The contemporary manager, envisioned as a hero able to save themselves and by proxy the corporation from stagnation and failure rather than a bureaucratic functionary at the mercy of fate, is a vision taken from the pages of Tools of Titans. By this insight, Ferriss's text can uncharitably be read as the climax, la petite mort, of a society-wide and Business School cultivated auto-erotic obsession with and around the image of the strong, visionary and transformational leader that we collectively construct in order to at once place our hope in and also castigate and vilify as the evil of contemporary, patriarchal, destructive, and disposable capitalism. However, as we have developed previously, the question of why such a figure might be of such appeal to us is still in need of further academic work.

As such, it is in the ineffable tone of the text that this paper finds the most substantive scope for such development. For this paper, building upon Deleuze and Guattari, the question of microfascism emerges as being of central importance to the consideration of the success of Ferriss's project. He is not just a purveyor of life-advice, and what he offers is not to be dismissed as the allure of the 'fascist demagogue' surrounded by a cult of personality. He is not so much actively courting a repressed and servile following as he is encouraging freedom and self-experimentation. As he says: 'this book, like my others, is a compendium of recipes for high performance that I gathered for my own use.' (Ferriss 2016, xvi). He encourages readers to skip around, to experiment and seek out advice that works for them. The preface unabashedly says to the reader, who may come to idolise the visionaries and leaders who are chronicled therein: 
These world-class performers don't have super powers. The rules they've crafted for themselves allow the bending of reality to such an extent that it may seem that way, but they've learnt how to do this and so can you (Ferriss 2016, xix).

While the tone of a text is notoriously difficult to quantify, it is the way that Ferriss writes which most reflects and legitimates our preoccupation with the microfascistic. His style evokes a certain seduction which impels us to think through the question of how desire can come to desire its own repression. The experience of reading the text is overwhelming with its quasi-aphoristic lessons being so impactful that even the most cynical of readers can be drawn in to think about how they might take its inspirations and apply them to their own lives. Indeed, even the present author was often 'duped' into daydreaming while trying to parse Ferriss's 674 page volume, beguiled into fantasizing about the ways in which a trite lesson like 'we all begin with suck' (Ferriss 2016, 310) or 'we all fail at the beginning' might be adapted into helpful advice to aid, for example, a student struggling with their self-confidence in essay writing. That is to say, even if one is aware of the nature of the guru's design, an excerpt like the following, which emerges from his interview with researcher Jane McGonigal, is overtly captivating:

Have trouble getting to sleep? Try 10 minutes of Tetris. Recent research has demonstrated that Tetris - or Candy Crush Saga or Bejeweled - can help overwrite negative visualization. (Ferriss 2016, 133)

Speaking directly to the reader and seeming to offer insight into their life experiences, Ferriss's text is written with a very particular tone that renders his advice alluring, accessible and attractive. There are strong resonances here with the ways in which previous scholarship has described the appeal and accessibility of the guru's writings as well as their charisma and charm. This is certainly borne out through Ferriss's public lectures which are comparable in their 
seduction to those of more established and famous management gurus. However, to return to the work of Collins (2005) and others aforementioned, the complicity of the reader/manager in seeking out the guru's practice is not to be underestimated. Ferriss's text is far from authoritarian in its prescriptions; it is inviting, encouraging and motivates the individual to engage in their own self-development. This self-development is, however, always by way of an abdication of responsibility and choice in capitulation to the ideas of the guru, a capitulation borne out of the microfascist impulse. The work of Sturdy (1997) is here invaluable in reminding us that the consultant (or guru) is as riddled with anxiety as their client, plagued by the same stresses of work and the same existential uncertainties, but the question of microfascism compels us to consider further that we both follow and want others to follow the 'rules' that the guru prescribes. The reader/manager 'desires' to construct their own identity as servile and incapacitated by the many stresses and challenges of contemporary capitalism while still retaining the potential to transform themselves into the image of a guru whose identity, power and persuasion they are also in the process of affirming and legitimating, even as much as the converse is true.

In the final analysis, it is possible to suggest that what Ferriss offers is a critical programme. Not critique as in the sense advanced by the Frankfurt School, nor even critique as it is often deployed within Critical Management Studies vis a vis opposition to the mainstream or as regards the question of alternatives to capital and dominant modes of organization (Parker, Fournier, and Reedy 2007), but still 'critical' in the sense of the response of a critic to a crisis. Etymologically, the words 'crisis', 'critic', and 'critical' all coevolve from the Greek krinein

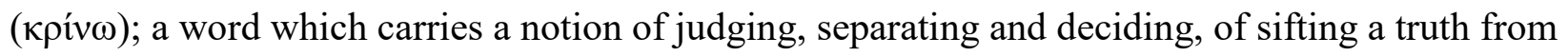
turbulent and uncertain times. Ferriss presents his work as that produced through careful 
consideration of the questions about health and humanity, exercise and existentialism, that plague the modern individual and offers an accessible response: a comprehensive guide to living that can permeate every aspect of life. He encourages exercise, healthy eating, and a certain rhetoric of carpe diem. This is the microfascist allure of the management guru, and it goes beyond what organizational scholars like Clark and Salaman have catalogued as their orientation towards action and tendency to advocate for change, in order to represent a 'critical' alternative to a given organizational or social state of affairs, a response to the burdens of being free within the contemporary social milieu. Indeed, it is precisely this position of presenting an 'alternative' to some 'mainstream' of being uncertain and anxious about what to do, what rules to follow, in the context of late capitalism that makes the guru so appealing.

This critical programme is one which, in the language of Deleuze and Guattari, is comprised of microfascisms. If we recall that for Deleuze and Guattari (2005, 9-10) 'groups and individuals contain microfascisms just waiting to crystallize', it becomes simple to read Ferriss's programme as one which taps into feelings of uncertainty and anxiety which characterize the human condition but are exacerbated by the nature of contemporary capitalism, in order to replace the fascist at the State level with one that forms part of one's everyday politics. This is a regime of control which is wilfully adopted in the name of 'management success' (whether this is interpreted as self-management or otherwise) which functions to construct the identity of a 'Titan' or similarly transformational leader in a manner which reverberates out from the everyday to produce the same formulations at the level of the state. We must thus reflect, returning to Deleuze and Guattari, that it is all too easy to oppose the image of the guru wrapped in overtly fascist tropes and neglect to consider how we are complicit in their construction and legitimation. Desire is not coded through fear nor through perversion nor ignorance nor the allure 
of the fascist leader, rather it is the case that the microfascist impulse emerges as a response to desire's own polymorphously perverse productions; in its tendency to always seek out freedom or new forms of expression and gratification, it adopts a programme of instructions, rules, and conformity. As such, while readers might take a bit of health advice here and an inspirational quote there, the reader and Ferriss are both complicit in an intimate relationship of desire for control, order, precision and efficiency; all precursors to the unattainable but still coveted goal of 'life success' which we have come to desire.

It is this complex of psychosocial forces that underpins the success of the guru. It is both why he undertakes his craft (Ferriss describes himself as a 'human guinea pig' who is always in the process of actively experimenting with the creation of new regimes of behaviour to disseminate to his readers) and why the reader seeks out his advice, buys his books and listens to his podcasts. In this regard, in constructing the image of the 'Titan' Ferriss simultaneously creates an incredibly potent and powerful image of a captain of industry and wider life, while also constructing the image of a frustrated, beleaguered and lost reader who will take his advice in order to build themselves into a Titan, even as much as Ferriss constructs himself by the same dichotomy.

It is thus that we reflect that Ferriss's entire project will always have been contingent upon the entrepreneurial logic of the self-determining, autonomous neoliberal subject often construed as an image of individual freedom and liberty. What Ferris shows thereby is how far fascism can extend, far beyond what Deleuze and Guattari may have originally considered. Though they do say 'desire stretches that far: desiring one's own annihilation, or desiring the power to annihilate. Money, army, police, and State desire, fascist desire, even fascism is desire' (Deleuze and Guattari 2005, 165) this is a far cry from describing the recodification of desire for 
repression $a s$ the desire for freedom. That is to say, working through Ferriss, we might see a fascism that people not only cry out for at a particular moment but one which they view as freedom because it offers some alternative (and a 'critical' alternative at that) to the regimes in which they live. Here the micropolitics of fascism begins to be entangled with and inform macropolitical fascist formations or what Evans and Reid (2013, 3) call 'liberal fascism', the 'inherently fascist character of liberal modernity itself'. Here, reading Deleuze and Guattari through Ferriss's project is not only productive but necessary in order to understand the full extent and scope of microfascism within the contemporary social milieu, even as much as the converse is true: fascism is now disguised as self-help advice within a veil of individual freedom, transformation and self-discovery.

\section{Conclusion: Unmaking microfascist subjectivities}

This paper has endeavoured to demonstrate that what Deleuze and Guattari term 'microfascism' is of crucial importance to an understanding of the politics of contemporary organization in the broadest terms, illustrating this through the analysis of Tim Ferriss's Tools of Titans. What we wish to underscore in conclusion is that the allure of the guru is intimately linked to the microfascist impulse and that through understanding it we can develop effective strategies for engaging in organizational life.

However, we must stress caution in this analysis. It is not this paper's intention to reduce the word 'fascist' to a bland or generic insult which can be hurled at someone vying for power or exerting bureaucratic or State control. We do not wish to throw labels at the management guru in lieu of academic analysis, nor do we wish to dismiss Ferriss as a fascist or suggest that his is an inherently malicious project. Rather, it is the case that we wish to elucidate the work of the 
management guru and in so doing, bring to the fore the concept of microfascism as a tool for the analysis of the draw of the management guru within the contemporary milieu. It seems all too often the case that the microfascist impulse goes unconsidered though it informs organization by shaping how we experience the social.

Where we should look to next is neatly summarized by Guattari in an interview originally published in 1973, Capitalism: A very special delirium. Discussing the consistent failure of revolutionary action and the state of then contemporary politics, Guattari says:

a simple dilemma: either one finds a new type of structure that finally moves toward the fusion of collective desire and revolutionary organization, or one continues on the present path and, going from repression to repression, heads for a new fascism that makes Hitler and Mussolini look like a joke. (Guattari 2009, 46)

It is abundantly clear that both Deleuze and Guattari lived with the fear of a coming fascism that would surpass, if not the barbarism of the past, then certainly the intense cravings for repression, unfreedom, subordination, and control that informed their present. Building off this, and in keeping with a micropolitics, it is thus essential that we understand the ways in which desire, and we as we are constituted by desire, is mobilized in order to desire fascism. If we are attentive to our own microfascisms and, in the case of this paper, those elicited by the management guru, we can both better understand their popularity amongst students, practitioners and the general public and also aid in the unmaking of the dystopian future that Deleuze and Guattari foresaw; one wherein freedom, emphasised and marketed to the point of being altogether burdensome, was abdicated in favour of a desire to be controlled.

What is necessary are political strategies that render the burdens of freedom, in all of its iterations under neoliberal capitalism, bearable. That is to say, we need to shape our resistance 
and revolution at both the micro and macro-levels, through collective action and the diligent unmaking of the various subordinated subjectivities that we are accorded as well as those which we actively court. As Guattari says elsewhere:

A micropolitics of desire means that henceforth we will refuse to allow any fascist formula to slip by, on whatever scale it may manifest itself, including within the scale of the family or even within the scale of our own personal economy. (Guattari 2009, 166) Here the 'politics' of organization can be meaningfully redefined to say, following Deleuze and Guattari $(2005,213)$, that 'everything is political, but every politics is simultaneously a macropolitics and a micropolitics' and thereby to suggest that we can begin to think of our mobilizations against state-level fascist undertakings as or through the experience of the desire for unfreedom on the micro-level. This is a politics capable of apprehending the ways in which 'power' can be truly dissipated throughout the social fabric, as the effects of the management guru seem to be, and manifests only in the production of certain forms of subjectivity, those of the guru and their reader. This is a politics capable of responding when the guru speaks, and recognizing that only reason that the microfascist impulse does not repulse or disturb us is because it is collectively legitimated and accepted. Instances of hostility to outsiders, disciplinary policing, road-rage, or anger at people standing of the wrong side of the escalator on our morning commute, are the subject of jokes and humorous anecdotes both within the modern corporation and without. In these examples, much like Ferriss's life advice, we see legitimated and reinforced our desire for repression, conformity and rule-following. Thus, the management guru only subsists within our society because we deem such figures acceptable and leave unaddressed the complex of desire for repression upon which they trade. It is here that the subject as constructed by the regimes of neoliberal capital finds its true expression and an aspirational limit: 
a protofascist serf to whose identity, games, and plays we capitulate. It is with this figure that we must begin the long process of unmaking and denaturalizing the microfascist impulse in everyday social life.

To do this, we must reconcile ourselves to the admittedly terrifying possibilities of freedom in a non-fascist life and be sensitive to the degree to which we often cultivate our microfascist desires and grow them into images of freedom. Here the tasks of schizoanalysis outlined by Deleuze and Guattari in Anti-Oedipus might offer some means of developing an active practice of resistance to microfascist impulses. That is to say, understanding the ways in which one's desire is coded by the social and, among other things, scouring the unconscious of the means by which desire for fascism is cultivated. This is a long and draw-out labour that involves the development of a reflexive practice of self-scrutiny to understand how our individual desires and anxieties are mobilized by broader social forces which might render us both amenable to and desirous of guru theory (and vice versa). This is essential, for unless we can understand the microfascist impulse and develop strategies and practices to cultivate other forms of coding desire, the management guru, and the complex of repression that they are complicit in, will be here to stay.

\section{$\underline{\text { Acknowledgements }}$}

I am grateful to the editor and the three reviewers of this paper for their patience and careful commentary. I would also like to thank the members of the People, Management and Organizations group and the Centre for Critical Thought at the University of Kent for their comments on earlier versions of this paper. Most of all, I would like to thank the student who walked into my classroom carrying a copy of Tools of Titans in the autumn of 2016. I hope that this paper adequately explains why I was sceptical of it. 


\section{References}

Abrahamson, Eric. 1991. "Managerial Fads and Fashions : The Diffusion and Rejection of Innovations." Academy of Management 16 (3): 586-612. doi:10.2307/258919.

Abrahamson, Eric. 1996. “Management Fashion.” Academy of Management Review 21 (1): 254285. doi:10.2307/258919.

Abrahamson, Eric, and Gregory Fairchild. 1999. "Management Fashion: Lifecycles, Triggers, and Collective Learning Processes." Adminstrative Science Quarterly 44 (4): 708-740. doi: $10.2307 / 2667053$.

Alvesson, Mats, and Andre Spicer. 2012. "Critical Leadership Studies: The Case for Critical Performativity.” Human Relations 65 (3): 367-390. doi:10.1177/0018726711430555.

Benders, Jos, and Kees Van Veen. 2001. "What's in a Fashion? Interpretative Viability and Management Fashions.” Organization 8 (1): 33-53. doi:10.1177/135050840181003.

Carlone, David. 2006. "The Ambiguous Nature of a Management Guru Lecture: Providing Answers While Deepening Uncertainty." Journal of Business Communication 43 (2): 89112. doi: $10.1177 / 0021943605285354$.

Carnegie, Dale. 1936. How to Win Friends and Influence People. New York: Pocket Books.

Cederström, Carl, and Andre Spicer. 2015. The Wellness Syndrome. Cambridge: Polity.

Chia, Robert. 1999. “A 'Rhizomic' Model of Organizational Change and Transformation: Perspective from a Metaphysics of Change." British Journal of Management 10 (3): 209227. doi:10.1111/1467-8551.00128.

Clark, Timothy. 2004. "The Fashion of Management Fashion: A Surge Too Far?” Organization 11 (2): 297-306. doi:10.1177/1350508404030659.

Clark, Timothy, and Graeme Salaman. 1996. "The Management Guru as Organizational Witchdoctor.” Organization 3 (1): 85-107. doi:10.1177/135050849631005.

Clark, Timothy, and Graeme Salaman. 1998. "Telling Tales: Management Gurus' Narratives and the Construction of Managerial Identity." Journal of Management Studies 35 (2): 137-161. doi:10.1111/1467-6486.00088.

Clegg, Stewart, Martin Kornberger, and Carl Rhodes. 2005. "Learning/Becoming/Organizing." Organization 12 (2): 147-167. doi:10.1177/1350508405051186.

Collins, David. (Forthcoming) "Management's Gurus." In The Oxford Handbook of Management Ideas, edited by Andrew Sturdy, Stefan Heusinkveld, Trish Reay, and David Strang. Oxford: Oxford University Press.

Collins, David. 2001. “The Fad Motif in Management Scholarship.” Employee Relations 23 (1): 
26-37. doi:10.1108/01425450110366255.

Collins, David. 2005. "Pyramid Schemes and Programmatic Management: Critical Reflections on the 'Guru Industry." Culture and Organization 11 (1): 33-44. doi:10.1080/14759550500062318.

Collins, David. 2008. "Has Tom Peters Lost the Plot? A Timely Review of a Celebrated Management Guru." Journal of Organizational Change Management 21 (3): 315-334. doi:10.1108/09534810810874804.

Collins, David. 2011. "Women Roar : 'The Women's Thing' in the Storywork of Tom Peters." Organization 19 (4): 405-424. doi:10.1177/1350508411408173.

Collins, David. 2016. "Constituting Best Practice in Management Consulting." Culture and Organization 22 (5). Taylor \& Francis: 409-429. doi:10.1080/14759551.2014.983109.

Collinson, David. 2003. "Identities and Insecurities: Selves at Work." Organization 10 (3): 527547. doi:10.1177/13505084030103010.

Collinson, David. 2011. "Critical Leadership Studies.” In The Sage Handbook of Leadership, edited by A. Bryman, D. Collinson, K. Grint, B. Jackson, and M. Uhl-Bein. London: Sage. doi: $10.1177 / 1742715013510807$.

De Cock, Christian, and Ian Hipkin. 1997. "TQM and BPR: Beyond the Beyond Myth." Journal of Management Studies 34 (5): 659-675. doi:10.1111/1467-6486.00067.

Deleuze, Gilles. 2004. Desert Islands and Other Texts 1953-1974. Semiotext(e) Foreign Agents Series. Los Angeles, CA: Semiotext(e).

Deleuze, Gilles. 2006. Two Regimes of Madness. New York: Semiotext(e).

Deleuze, Gilles, and Felix Guattari. 2005. A Thousand Plateaus: Capitalism and Schizophrenia. London: University of Minnesota Press.

Deleuze, Gilles, and Félix Guattari. 2000. Anti-Oedipus: Capitalism and Schizophrenia. Minneapolis: University of Minnesota Press.

Eco, Umberto. 1995. "Ur-Fascism.” The New York Review of Books. http://www.nybooks.com/articles/1995/06/22/ur-fascism/.

Evans, Brad, and Julian Reid, eds. 2013. Deleuze \& Fascism: Security, War, Aesthetics. Oxon: Routledge.

Ferriss, Tim. 2016. Tools of Titans: The Tactics, Routines and Habits of Billionaires, Icons and World-Class Performers. London: Vermilion.

Fromm, Erich. 2001. The Fear of Freedom. Oxon: Routledge.

Fuglsang, Martin, and Steffen Böhm. 2003. "The Rest Is Silence: A Remark on the Micro- 
Fascism of Critique." Ephemera 3 (4): 356-361. doi:62.

Fuglsang, Martin, and Bent Meier Sørensen, eds. 2006. Deleuze and the Social. Edinburgh: Edinburgh University Press.

Gabriel, Yiannis. 2002. "Essal: On Paragrammatic Uses of Organizational Theory - A Provocation." Organization Studies 23 (1): 133-151. doi:10.1177/017084060202300107.

Garsten, Christina, and Christopher Grey. 1997. "How to Become Oneself: Discourses of Subjectivity in Postbureaucratic Organizations." Organization 4 (2): 211-228. doi:10.1177/135050849742004.

Greatbatch, David, and Timothy Clark. 2005. Management Speak: Why We Listen to What Management Gurus Tell Us. Oxon: Routledge.

Grey, Christopher. 1999. “'We Are All Managers Now'; 'We Always Were': On the Development and Demise of Management." Journal of Management Studies 36 (5). doi:10.1111/1467-6486.00149.

Grint, Keith. 1997. Fuzzy Management: Contemporary Ideas and Practices at Work. Oxford: Oxford University Press.

Guattari, Félix. 1984. Molecular Revolutions: Psychiatry and Politics. Harmondsworth: Penguin Books.

Guattari, Félix. 2009. Chaosophy: Texts and Interviews, 1972-1977. Los Angeles, CA: Semiotext(e).

Holland, Eugene. 2008. "Schizoanalysis, Nomadology, Fascism." In Deleuze and Politics, edited by Ian Buchanan and Nicholas Thoburn, 74-98. Edinburgh: Edinburgh University Press.

Huczynski, Andrzej. 1992. "Management Guru Ideas and the 12 Secrets of Their Success." Leadership \& Organization Development Journal 13 (5): 15-20. doi:10.1108/01437739210016196.

Huczynski, Andrzej. 1993a. Management Gurus: What Makes Them and How to Become One. New York: Routledge.

Huczynski, Andrzej. 1993b. "Explaining the Succession of Management Fads.” The International Journal of Human Resource Management 4 (2): 443-464. doi:10.1080/09585199300000023.

Iacocca, Lee A., and William Novak. 1987. Iacocca: An Autobiography. London: Bantam Books.

Jackson, Brad. 2001. Management Gurus and Management Fashions. London: Routledge.

Legge, Karen. 2002. "On Knowledge, Business Consultants and the Selling of Total Quality 
Management." In Critical Consulting: New Perspectives on the Management Advice Industry, edited by Timothy Clark and Robin Fincham, 74-92. Oxford: Blackwell Publishers.

Lewis, Tim. 2017. “Tim Ferriss: 'I'm a Coyote, a Merry Prankster, a Go-between'.” The Observer, January 15.

Linstead, Stephen, and Torkild Thanem. 2007. "Multiplicity, Virtuality And Organization: The Contribution Of Gilles Deleuze.” Organization Studies 28 (10): 1483-1501. doi:10.1177/0170840607075675.

Maravelias, Christian. 2003. "Post-Bureaucracy - Control through Professional Freedom." Journal of Organizational Change Management 16 (5): 547-566. doi:10.1108/09534810310494937.

Massumi, Brian. 1992. A User's Guide to Capitalism and Schizophrenia: Deviations from Deleuze and Guattari. London: The MIT Press.

McCann, Leo, John Hassard, Edward Granter, and Paula Hyde. 2015. "Casting the Lean Spell: The Promotion, Dilution and Erosion of Lean Management in the NHS." Human Relations 68 (10): 1557-1577. doi:10.1177/0018726714561697.

Micklethwait, John, and Adrian Wooldridge. 1996. The Witch Doctors: Making Sense of the Management Gurus. New York: Times Books.

Mintzberg, Henry. 1973. The Nature of Managerial Work. New York: Harper \& Row Publishers.

Newell, Sue, Maxine Robertson, and Jacky Swan. 2001. "Management Fads and Fashions." Organization 8 (1): 5-15. doi:10.1177/135050840181001.

Parker, Martin. 2003. "Introduction: Ethics, Politics and Organizing.” Organization 10 (2): 187203. doi:10.1177/1350508403010002001.

Parker, Martin, Valerie Fournier, and P Reedy. 2007. The Dictionary of Alternatives: Utopianism and Organization. London: Zed Books.

Passmore, Kevin. 2002. Fascism: A Very Short Introduction. Oxford: Oxford University Press.

Pedersen, Michael, and Anders Raastrup Kristensen. 2016. “'Blowing up the Pylon’: The Limitations to Lacanism in Organization Studies, Seen from the Perspective of Deleuze and Guattari." Culture and Organization, 1-13. doi:10.1080/14759551.2016.1230855.

Peters, Thomas, and Robert Waterman. 1982. In Search of Excellence: Lessons from America's Best-Run Companies. New York: Harper \& Row Publishers.

Renton, David. 1999. Fascism : Theory and Practice. London: Pluto Press.

Salaman, Graeme. 2002. "Understanding Advice: Towards a Sociology of Management 
Consultancy." In Critical Consulting: New Perspectives on the Management Advice Industry, edited by Timothy Clark and Robin Finchman, 247-259. Oxford: Blackwell Publishers.

Sørensen, Bent Meier. 2005. "Immaculate Defecation: Gilles Deleuze and Felix Guattari in Organization Theory." The Sociological Review 53: 120-133. doi:10.1111/j.1467954X.2005.00545.x.

Spicer, Andre. 2018. Business Bullshit. Oxon: Routledge.

Sturdy, Andrew. 1997. "The Consultancy Process - An Insecure Business?” Journal of Management Studies 34 (3): 389-413. doi:10.1111/1467-6486.00056.

Styhre, Alexander. 2002. "Thinking with AND: Management Concepts and Multiplicities." Organization 9 (3): 459-475. doi:10.1177/135050840293012.

ten Bos, René, and Stefan Heusinkveld. 2007. "The Guru's Gusto: Management Fashion, Performance and Taste.” Journal of Organizational Change Management 20 (3): 304-325. doi:10.1108/09534810710740155.

Thanem, Torkild. 2004. "The Body without Organs: Nonorganizational Desire in Organizational Life." Culture and Organization 10 (3): 203-217. doi:10.1080/14759550412331297147.

Watson, Tony J. 1994. "Management 'Flavours of the Month': Their Role in Managers' Lives." The International Journal of Human Resource Management 5 (4): 893-909.

Whittle, Andrea. 2008. "From Flexibility to Work-Life Balance: Exploring the Changing Discourses of Management Consultants." Organization 15 (4): 513-534. doi: $10.1177 / 1350508408091005$.

Willmott, Hugh. 1994. "Business Process Re-engineering and Human Resource Management." Personnel Review 23 (3): 34-46. doi:10.1108/00483489410064559. 